\title{
Replacement of the Type Strain of Streptococcus mitis Request for an Opinion
}

\author{
MOGENS KILIAN, ${ }^{1 *}$ LENA MIKKELSEN, ${ }^{2}$ AND JøRGEN HENRICHSEN ${ }^{3}$ \\ Departments of Oral Biology ${ }^{1}$ and Oral Medicine and Diagnosis, ${ }^{2}$ Royal Dental College, DK-8000 Aarhus C, Denmark, \\ and Streptococcus Department, Statens Seruminstitut, DK-2300 Copenhagen S, Denmark
}

\begin{abstract}
The type strain of Streptococcus mitis Andrewes and Horder 1906, 712 is strain NCTC 3165. This strain was arbitrarily designated as the type strain on the 1980 Approved Lists of Bacterial Names before adequate documentation of its characteristics. It is not an authentic strain of Andrewes and Horder; subsequent examination has indicated that it almost certainly is not representative of the species described by these authors, nor is it representative of strains widely recognized as $S$. mitis. We propose replacement of strain NCTC 3165 with strain NCTC 12261 as the type strain of $S$. mitis.
\end{abstract}

The name Streptococcus mitis was applied by Andrewes and Horder in 1906 (1) to streptococci that were considered saphrophytes of saliva and feces. These authors separated $S$. mitis from Streptococcus pyogenes because $S$. mitis grew as short chains and rarely caused disease. $S$. mitis was further characterized by its ability to grow well at $20^{\circ} \mathrm{C}$, by being unable to clot milk, and by fermenting sucrose and lactose. Many strains fermented salicin and coniferin, but few representatives fermented inulin. No strain studied by Andrewes and Horder is available, and it is likely that the strains studied by these authors represented more than one species according to current streptococcal taxonomy.

Based on an examination of a large collection of strains cultured from human throats, Sherman et al. (13) noted the heterogeneity of strains assigned to $S$. mitis and that the taxon lacked clearly marked characteristics, uniquely its own, which would allow rapid and positive identification by the use of only a few simple tests. However, the 147 strains assigned to $S$. mitis by these authors could be distinguished from other named species notably by their inability to ferment inulin and to produce extracellular dextran or levan and by rarely being able to hydrolyze esculin (Table 1). Subsequent descriptions of $S$. mitis in Bergey's Manual of Determinative Bacteriology (2) have been based on the results published by Sherman et al. (13). This definition of the species also concurs with that used by several authorities in the field $(3,7)$ (Table 1 ) and in commercial identification kits widely used in clinical microbiological laboratories.

Coleman and Williams (4) convincingly argued that the name $S$. mitis is a later synonym for "Streptococcus mitior seu viridans," which was proposed by Schottmüller in 1903 (12). Although the name " $S$. mitior" has been widely used in some parts of the world, it was not included on the 1980 Approved Lists of Bacterial Names (14) and has no formal standing in nomenclature.

In contrast to " $S$. mitior," $S$. mitis was included on the 1980 Approved Lists (14), with reference to the description given in Bergey's Manual, 8th ed. (2), which was based on the publication by Sherman et al. (13). "Streptococcus sp. viridans type" strain NCTC 3165 (= ATCC 33399), which was isolated from pyorrhoea in 1930 , was arbitrarily designated the type strain before adequate documentation of its characteristics. Subsequent examination has disclosed that this strain differs from the descriptions of the species given

\footnotetext{
* Corresponding author.
}

by both Andrewes and Horder (1) and Sherman et al. (13), notably in its ability to ferment inulin and to hydrolyze both arginine and esculin $(10,16)$ (Table 1). Furthermore, deoxyribonucleic acid (DNA)-DNA hybridization tests revealed that strain NCTC 3165 is only moderately related $(41 \%)$ to strains fitting the description of $S$. mitis (16). The results of our taxonomic study, which are described in the accompanying paper (9), as well as the results of our recent genetic study (8), reveal that strain NCTC 3165 is an atypical member of a taxon that is proposed as a new species, which is characterized by inulin fermentation, arginine and esculin hydrolysis, production of extracellular dextran from sucrose, $\beta$-glucosaminidase and $\alpha$-L-fucosidase activities, and lack of immunoglobulin A1 protease activity (9). The relationship of strain NCTC 3165 to other members of this new species has been confirmed by DNA-DNA hybridization experiments (16).

Because strain NCTC 3165 almost certainly is not representative of $S$. mitis as originally described, was not properly documented before its assignment to the status of type strain, and is not representative of the species as defined by clinical microbiological laboratories, we believe that it is not a valid type strain. Conservation of strain NCTC 3165 as the type strain will mean that it becomes a phenotypically (9) and genetically (8) atypical representative of a species which is characterized by dextran production, by arginine and esculin hydrolysis, and by the ability to ferment inulin. As these phenotypic traits have traditionally excluded a diagnosis of $S$. mitis, the situation would, in our opinion, create confusion. We propose strain NCTC 12261 as the valid type strain of $S$. mitis in agreement with the results described in the accompanying paper (9).

We request that the Judicial Commission rule that strain NCTC 3165 is not the valid type strain of $S$. mitis according to Rule $18 \mathrm{~g}$ (15) (formerly Rule $18 \mathrm{i}$ [11]), which states that if a type strain has become unsuitable due to changes in its characteristics or for other reasons, the matter should be referred to the Judicial Commission, which may take action leading to replacement of the strain. We further request that the Judicial Commission designate strain NCTC 12261 as the type strain of $S$. mitis. Pending the decision of the Judicial Commission, we have offered an emended description of $S$. mitis in the accompanying paper (9).

After the submission of this request, Coykendall published a request to reject strain NCTC 3165 as the type strain of $S$. mitis (5). He proposes that $S$. oralis be considered a later 
TABLE 1. Phenotypic characteristics of $S$. mitis as defined by selected authors, of the present type strain (strain NCTC 3165), and of the strain (strain NCTC 12261) by which it is proposed to be replaced

\begin{tabular}{|c|c|c|c|c|c|c|}
\hline \multirow{3}{*}{ Characteristic } & \multicolumn{4}{|c|}{$\%$ of strains positive in the study of: } & \multicolumn{2}{|c|}{ Reaction of: } \\
\hline & \multirow{2}{*}{$\begin{array}{l}\text { Sherman } \\
\text { et al. }{ }^{a}\end{array}$} & \multirow{2}{*}{ Facklam $^{b}$} & \multicolumn{2}{|c|}{ Kilian et al. ${ }^{c}$} & \multirow{2}{*}{$\begin{array}{c}\text { Strain } \\
\text { NCTC } \\
3165^{c}\end{array}$} & \multirow{2}{*}{$\begin{array}{l}\text { Strain } \\
\text { NCTC } \\
12261^{\circ}\end{array}$} \\
\hline & & & $\begin{array}{c}\text { Biovar } \\
1\end{array}$ & $\begin{array}{l}\text { Biovar } \\
2\end{array}$ & & \\
\hline $\begin{array}{l}\text { Arginine hydro- } \\
\text { lysis }\end{array}$ & 43 & 16 & 0 & 100 & + & - \\
\hline $\begin{array}{l}\text { Esculin hydro- } \\
\text { lysis }\end{array}$ & 21 & 0 & 0 & 0 & + & - \\
\hline $\begin{array}{l}\text { Dextran produced } \\
\text { from sucrose }\end{array}$ & 0 & 10 & 0 & 0 & - & - \\
\hline \multicolumn{7}{|l|}{ Fermentation of: } \\
\hline Inulin & 0 & 0 & 0 & 0 & + & - \\
\hline Raffinose & 32 & 0 & 70 & 100 & - & + \\
\hline Salicin & 74 & 28 & 20 & 39 & + & - \\
\hline Threhalose & 15 & 25 & 30 & 8 & + & - \\
\hline Lactose & 100 & 100 & 100 & 100 & + & + \\
\hline
\end{tabular}

${ }^{a}$ Reference 13. The description of $S$. mitis in this reference is referred to in the Approved Lists of Bacterial Names (14).

${ }^{b}$ Reference 7.

${ }^{c}$ Reference 9.

synonym of $S$. mitis and that the present type strain of $S$. oralis (strain NCTC 11427) be adopted as the type strain of $S$. mitis. However, this proposal is in conflict with the DNA-DNA homology data reported by Coykendall and Munzenmaier (6), which show that $S$. oralis and $S$. mitis as defined by us on the basis of phenotypic and antigenic differences (9) share less than $40 \%$ DNA sequence homology.

\section{LITERATURE CITED}

1. Andrewes, F. W., and T. J. Horder. 1906. A study of the streptococci pathogenic for man. Lancet ii:708-713.

2. Buchanan, R. E., and N. E. Gibbons (ed.). 1974. Bergey's manual of determinative bacteriology, 8 th ed. The Williams \& Wilkens Co., Baltimore.

3. Carlsson, J. 1968. A numerical taxonomic study of human oral streptococci. Odontol. Revy 19:137-160.
4. Colman, G., and R. E. O. Williams. 1972. Taxonomy of some human viridans streptococci, p. 282-299. In L. W. Wannamaker and J. M. Matsen (ed.), Streptococci and streptococcal diseases. Academic Press, Inc., New York.

5. Coykendall, A. L. 1989. Rejection of the type strain of Streptococcus mitis (Andrewes and Horder 1906). Request for an opinion. Int. J. Syst. Bacteriol. 39:207-209.

6. Coykendall, A. L., and A. J. Munzenmaier. 1978. Deoxyribonucleic acid base sequence studies on glucan-producing and glucan-negative strains of Streptococcus mitior. Int. J. Syst. Bacteriol. 28:511-515.

7. Facklam, R. R. 1977. Physiological differentiation of viridans streptococci. J. Clin. Microbiol. 5:184-201.

8. Gilmour, M. N., T. S. Whittam, M. Kilian, and R. K. Selander. 197. Genetic relationships among the oral streptococci. J. Bacteriol. 169:5247-5257.

9. Kilian, M., L. Mikkelsen, and J. Henrichsen. 1989. Taxonomic study of viridans streptococci: description of Streptococcus gordonii sp. nov. and emended descriptions of Streptococcus sanguis (White and Niven 1964), Streptococcus oralis (Bridge and Sneath 1982), and Streptococcus mitis (Andrewes and Horder 1906). Int. J. Syst. Bacteriol. 39:471-484.

10. Kilian, M., B. Nyvad, and L. Mikkelsen. 1986. Taxonomic and ecological aspects of some oral streptococci, p. 391-400. In S. Hamada, S. M. Michalek, H. Kiyono, L. Menaker, and J. R. McGhee (ed.), Molecular microbiology and immunology of Streptococcus mutans. Elsevier Science Publishing Co., Inc., New York.

11. Lapage, S. P., P. H. A. Sneath, E. F. Lesssel, V. B. D. Skerman, H. P. R. Seeliger, and W. A. Clark (ed.). 1975. International code of nomenclature of bacteria. 1975 Revision. American Society for Microbiology, Washington, D.C.

12. Schottmüller, H. 1903. Die Artunterscheidung der für den Menschen pathogenen Streptokokken durch Blutagar. Muench. Med. Wochenschr. 50:849-853.

13. Sherman, J. M., C. F. Niven, Jr., and K. L. Smiley. 1943. Streptococcus salivarius and other non-hemolytic streptococci of the human throat. J. Bacteriol. 45:249-263.

14. Skerman, V. B. D., V. McGowan, and P. H. A. Sneath (ed.). 1980. Approved lists of bacterial names. Int. J. Syst. Bacteriol. 30:225-420.

15. Wayne, L. G., M. Goodfellow, J. G. Holt, and P. H. A. Sneath. 1982. Proposals to emend the International Code of Nomenclature of Bacteria. Int. J. Syst. Bacteriol. 32:142-143.

16. Welborn, P. P., W. K. Hadley, E. Newbrun, and D. M. Yajko. 1983. Characterization of strains of viridans streptococci by deoxyribonucleic acid hybridization and physiological tests. Int. J. Syst. Bacteriol. 233:293-299. 